Ghana Journal of Development Studies, Volume 7, Number 2 2010

\title{
INNOVATIONS ADOPTION LEVELS OF SMALL RUMINANT FARMERS IN TOLON-KUMBUNGU DISTRICT OF GHANA: The Role of Farmer Socio-Economic Characteristics
}

\author{
Hamza Adam ${ }^{3}$ \\ Department of Community Development \\ University for Development Studies, \\ Wa, Ghana \\ Email: hamzeet@yahoo.com \\ Pascal B. Atengdem \\ Department of Agricultural Extension \\ University of Ghana, Legon \\ Accra, Ghana \\ Email : atengdem@ug.edu.gh \\ and
}

Seidu Al-Hassan
Centre for Continuing Education and Interdisciplinary Research
University for Development Studies,
Navrongo, Ghana
Email: zodaseidu@yahoo.com

\begin{abstract}
The rearing of small ruminants plays a major role in the farming system of the people of the TolonKumbungu District of the Northern Region of Ghana. Small ruminant production is a major source of livelihood to over $70 \%$ of the inhabitants of the District. However, poor husbandry practices have often served as a major constraint to achieving production and productivity increases. This implies that small ruminant farmers need to adopt innovations in order to promote and sustain small ruminant production. This paper assesses the extent to which innovations introduced to the farmers in the study area are adopted, especially the role of farmer socio-economic characteristics in influencing the innovations adoption levels of small ruminants. A total of 120 small ruminant farmers were selected for the study using simple random sampling, and questionnaires and personal observations employed for the data collection. Twelve communities were randomly selected from four Ministry of Food and Agriculture operational zones. Data were analyzed using SPSS computer software package and descriptive statistics computed based on the data. Cross tabulation and other test statistics were used to determine the relationship between adoption levels and the variables studied. The findings show that, socio-economic characteristics such as extension contacts and credit access showed significance with respect to adoption of most of the innovations. Therefore, if adoption level is to be enhanced, attention should be focused more on training of more agriculture extension agents (AEAs) to increase their number in the area, as well as making affordable credit available and accessible to the farmers to expand their farms.
\end{abstract}

\footnotetext{
${ }^{3}$ Corresponding author.
} 
KEY DESCRIPTORS: Adoption, animals, credit, extension and small ruminants

\section{INTRODUCTION}

Ghana's economy is largely agro-based with the livestock sub-sector contributing about 25-30 percent to agriculture Gross Domestic Product (GDP) (ISSER, 2004). Livestock keeping makes significant contribution to rural livelihoods. It provides employment and serves as a source of wealth creation for reducing poverty. Koney (1992) explains that people keep animals as a source of wealth and for meeting their social and cultural obligations such as dowries, festivals and funerals. Animals may also be kept for occupational, sporting, religious and bride price payment reasons (Turner, 2007). In most cases livestock is the source of cash income for subsistent farmers as well as endurance of family purchasing power in the event of unprofitable agriculture due to natural calamities (Rahman, 2007).

Northern Ghana, comprising the Upper East, Upper West and Northern Regions is the livestock hub of the country (Dei et. al, 2007). The region is well known for the production of rural poultry (25\%), sheep $(30 \%)$, goats (35\%), pigs (40\%), and cattle (70\%). It ranks first in the livestock production of Ghana (Veterinary Services Department, 1997).

The Institute for Statistical, Social and Economic Research (ISSER) of the University of Ghana, Legon reported in 2006 that livestock production in Ghana is low compared to demand. This is attributable to the fact that the potential to develop and expand the animal sector is not fully tapped (Huq, 1989). Agtax (1996) argues that the country has a high potential to become self-sufficient in animal production, yet large quantities of meat are imported to meet demand. Meat imports for beef, buffalo, mutton, chicken and pork had risen during the period 2004 and 2007 (See Table 1 below).

Table 1: Distribution of meat imports (2004-2007) - Metric Tons

\begin{tabular}{|l|l|l|l|l|}
\hline Type of Meat & $\mathbf{2 0 0 4}$ & $\mathbf{2 0 0 5}$ & $\mathbf{2 0 0 6}$ & $\mathbf{2 0 0 7}$ \\
\hline Beef & $2,419.4$ & $6,331.7$ & $9,578.49$ & $16,250.37$ \\
\hline Buffalo & $1,169.2$ & $2,257.1$ & $4,498.96$ & $8,108.95$ \\
\hline Mutton & $1,797.1$ & $3,640.8$ & $4,445.04$ & $6,887.07$ \\
\hline Chicken & $34,265.8$ & 40,591 & 40,429 & $63,276.29$ \\
\hline Pork & $7,145.1$ & $10,286.8$ & $11,777.56$ & $10,551.50$ \\
\hline
\end{tabular}

Source: MOFA, 2007.

Small ruminant innovations are aimed at improving production and productivity as a means of ensuring increasing meat production, consumption as well as rural family income diversification. Until the 1990s, small ruminant innovations were not much emphasized in Ghana. This is because there were no major projects on livestock, including small ruminants. The first major project on livestock was the National Livestock S Project (NLSP) which started in July 1993. The NLSP promoted education on small ruminant innovations. Interventions through the NLSP did not, however, meet the desired impact due to the project's short duration and implementation problems (MOFA, 2008). In July 2003, the Livestock Development Project (LDP) was also launched to improve livestock production. Both projects emphasized improved husbandry practices in order to boost livestock production and productivity. In connection with that, a number of small ruminant innovations have been introduced to farmers across the country since the 1990s. Examples of the innovations are improved housing, supplementary feeding, record keeping, forage conservation and utilization, improved breeding, prophylactic treatment, 
castration and, general care and management. Agricultural institutions have been resourced by the government to carry out research and come out with technological innovations to be transferred to farmers by extension agents.

With all these ideas and efforts farmers are expected to adopt the innovations developed by the research institutions so as to be able to increase food production. The extent to which these innovations have been adopted by the farmers has not been well researched. Particularly, the socio-economic factors that govern the adoption of innovation have not been well researched. Previous works have placed much emphasis on adoption by crop farmers (Jatoe et al., 2005) and the economic importance of livestock as well as the challenges of adoption with little emphasis on adoption by small ruminant producers (Ogunlana, 2003; Latoper, 2001). If agricultural technologies developed for farmers in developing countries are not transferred to farmers in an appropriate manner and adopted accordingly, then all efforts by the researchers who develop the new technologies will be in vain (Rahman, 2007). Nevertheless, farmers' ability to adopt these innovations largely depends on their socio-economic characteristics (Rahman, 2007). The need to identify the socio-economic factors that contribute positively or otherwise to the adoption of new livestock technologies in the Tolon-Kumbungu District cannot be overemphasized.

This study sought answers to the following questions: What technologies exist for small ruminant production in the Tolon-Kumbungu District? To what extent do farmer socio-economic factors affect their adoption of these technologies? The overall objective of the paper is to determine the extent to which innovations have been adopted by small ruminant farmers in the Tolon-Kumbungu District of the Northern Region of Ghana. The paper specifically identifies and analyses the small ruminant production innovations in the study area and determines the effect of farmer socio-economic factors (farm size, income, credit access, extension contact, farm education exposure and farming experience) on adoption of small ruminant production innovations ${ }^{4}$. The rest of the paper deals with the conceptual framework, methodology, results and discussion of results and conclusions and recommendations.

\section{CONCEPTUAL FRAMEWORK}

Studies show that farmer decisions to adopt an innovation revolve around cost of innovations, frequency of extension contact, cultural factors and adequacy of knowledge of the innovations. Rogers (2003) states that innovation-decision is made through a cost-benefit analysis where the major obstacle is uncertainty. Farmers will adopt an innovation if they believe that it will, all things considered, enhance their utility. Harrison (1986) also noted that the first factor limiting pasture improvement is cost in relation to the expected returns and to the reliability of establishment and persistence. Thus, the level of adoption of innovations has been hypothesized to be influenced by both personal and socioeconomic characteristics of potential adopters (Figure 1). It is expected that the socio-economic characteristics would influence the farming system operated by the potential adopter, which would in turn influence their decision to adopt or not an innovation. Again, the farming system as well as the kind of innovation being introduced would have direct influence on the decision to adopt or not the innovations. Farmer motives and livelihood needs would have some interaction. Farmer motive for small ruminants innovation adoption would also be influenced by their motives and livelihood needs which in turn influence adoption. Sometimes, the compatibility of the farming system of the potential adopter to the innovations packaged would influence adoption of the innovations.

\footnotetext{
${ }^{4}$ Farmer demographic characteristics like age, sex, etc are excluded in the analysis because these factors are beyond the control of the farmer.
} 
Figure 1: Conceptual Framework

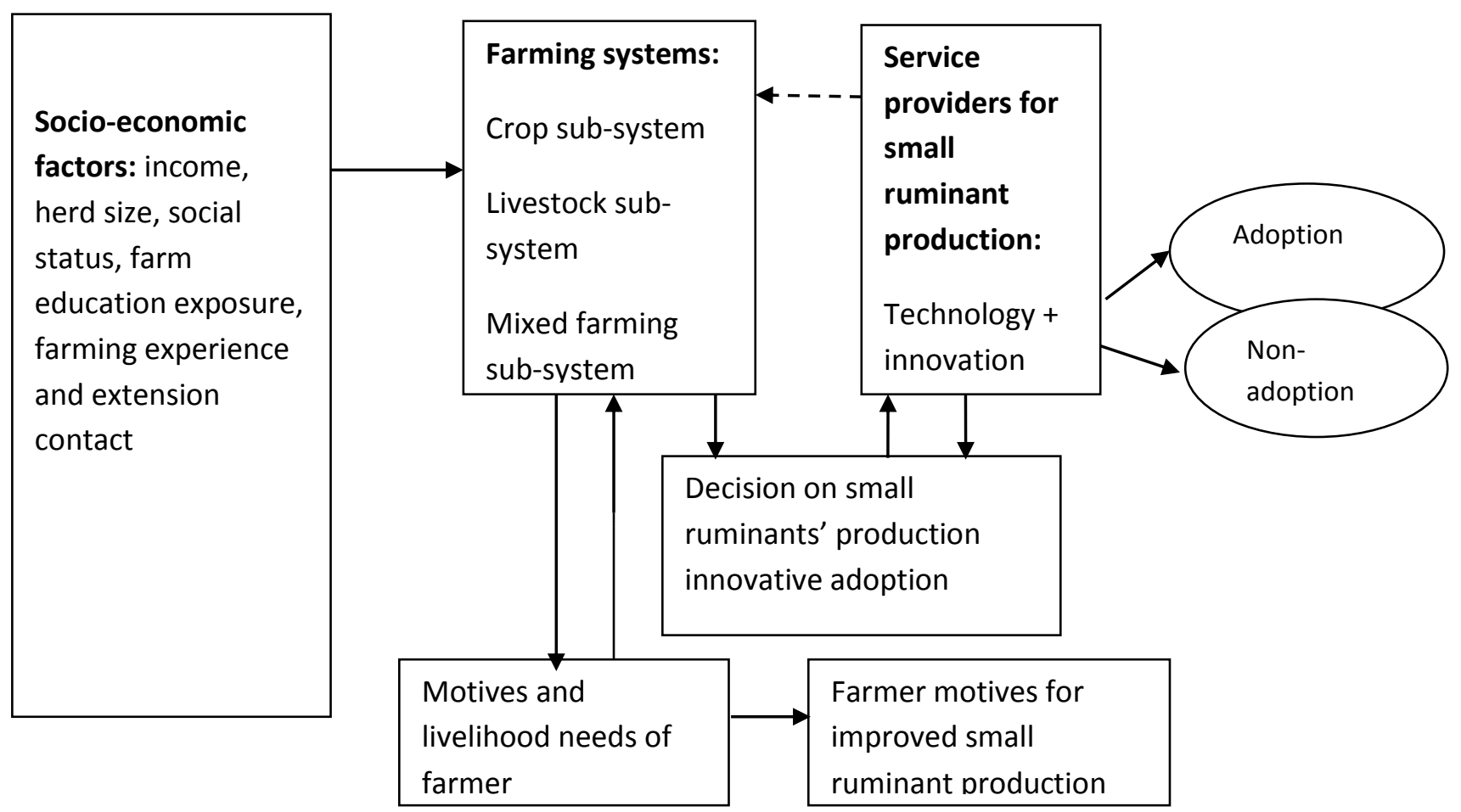

Source: Authors' Construct 2008

\section{METHODOLOGY}

\section{Description of the study area}

The Tolon/Kumbungu District (TKD) is one of the districts created through Provisional National Defence Council (PNDC) Law 207 in 1988 with Tolon as its Capital. The District covers an area of about 2,741 square kilometres and forms about 3.9\% of the total landmass of the Northern Region. The District, which lies between latitude 10-20 north and Longitude 10 to 50 west, shares border with West Mamprusi District in the North, West Gonja District in the West and South and the East with Savelugu/Nanton District and the Tamale Municipality. With an annual growth rate of about $2.8 \%$, the population is estimated at 145,876 with male representing $50.1 \%$ and female $49.9 \%$ of the number. The District has four agricultural operational zones, namely, the Tolon, Kumbungu, Nyankpala and Waantugu zones.

Due to poverty and related factors, the TKD has become a major sending destination of migrants to southern Ghana and beyond in search of jobs (Adama-Mohammed and Apusigah, 2005). The youth, boys and girls are prone to migrating to cities and towns such as Accra, Kumasi and Sekondi-Takoradi on seasonal basis. Ruminant production could serve as source of income and employment for such youth throughout the year and especially during off-farm season. Yet, animal production remains low despite the huge potential for enhancing small ruminant production in commercial quantities. More importantly, the adoption of innovations in farming has the potential of improving upon farming and reducing poverty in the area and help stem the migration of young women and men from the area to the south. The study results show that on average, livestock farmers are aged 40 years and that about $86 \%$ of the farmers no formal education (TKD, 2008). The Assembly of TKD 
reported in 2008 that the average household size of small ruminant farmers is high (10) with many of them engaged in the rearing of goats (78\%) and sheep (87\%).

\section{Sampling procedure}

The sampling was done at two levels. At the village level, twelve (12) villages were randomly sampled from the four MOFA operational zones in the district. The selection was based on a list of villages characterized by high rate of small ruminant production provided by MOFA. Specifically, Tolon, Tingoni and Waribogu communities were selected from zone one (Tolon zone) whereas communities like Kumbungu, Vagu Kpalsogu and Zangbalung were drawn from zone two (Kumbungu zone). Finally, Cheyohi, Mbanaayili and Bognaayili were selected from zone three (Nyankpala zone) followed by Waantugu, Yepalsi and Kpanyili from the Waantugu zone. At the individual farmer level, simple random sampling was used to sample ten (10) small ruminants' farmers from each community, bringing the total number of respondents to 120 . Personal observations were also made to confirm issues on the ground.

\section{Data analysis}

The independent variables used in the study are education level, family size, number of sheep, number of goats, income from sheep, income from goats, extension contact, farming experience, farm education exposure and credit received. Adoption was measured using level of practice. Respondents practicing the innovations in full were classified as "adopted", those combining new and old practice were termed as "partially adopted" and those practicing the entire old practice termed as "not adopted". To ensure that the data was amenable to the statistical test, "fully adopted" and "partially adopted" were combined and labelled as "adopted". A chi-square test was conducted to determine whether level of adoption of innovations was influenced by the independent variables (socio-economic characteristics). The independent variables were crosstabulated with the dependent variable and chi-square test performed to determine significance level of each of the independent variable with adoption of innovations.

\section{RESULTS AND DISCUSSIONS}

\section{Demographic Characteristics of Respondents}

Results of the study reveal that $50 \%$ of the farmers earn income less than or equal to 100 Ghana cedi per annum from sheep whereas $43 \%$ of the respondents earn income above 100 Ghana cedi per annum from sheep. Majority of the respondents (91\%) do not have access to any form of credit whereas $59 \%$ of the respondents never had extension contact. Sixty two percent (62\%) of the respondents have an average of 10 years experience of rearing small ruminants compared to $22 \%$ who have had farm education exposure.

Out of the 120 sampled farmers 31 and 89 belonged to the adopted and the not adopted categories, respectively. On supplementary feeding, 103 respondents adopted, while 17 did not adopt it. Adopted and not adopted categories were 22 and 98 respondents respectively for record keeping. Regarding forage preservation and utilization, 45 adopted whiles 75 respondents did not adopt. On prophylactic treatment, 95 and 25 belonged to the adopted and not adopted categories. Also, 90 and 30 respondents also belonged to the adopted and not adopted categories with regard to general care and management. On improved breeding, 8 and 112 belonged to the adopted and not adopted categories respectively. 
Generally, access to information on innovations was widespread. Out of the 120 respondents who were interviewed, $98.8 \%$ of them had access to information on improved housing, $99.2 \%$ on supplementary feeding, $98.3 \%$ on prophylactic treatment and $95.8 \%$ on forage preservation and utilization. Ninety percent each had access to information on record keeping and tagging (Table 1).

Table 1: Distribution by access to information on the innovations

\begin{tabular}{|l|l|l|l|}
\hline \multirow{2}{*}{ Innovation } & Frequency & \multirow{2}{*}{ Total } \\
\cline { 2 - 3 } & Yes (\%) & No (\%) & 120 \\
\hline Improved housing & $118(98.3)$ & $2(1.7)$ & 120 \\
\hline Supplementary feeding & $119(99.2)$ & $1(0.8)$ & 120 \\
\hline Record keeping & $108(90.0)$ & $12(10.0)$ & 120 \\
\hline Forage preservation and utilization & $115(95.8)$ & $5(4.2)$ & 120 \\
\hline Prophylactic treatment & $118(98.3)$ & $2(1.7)$ & 120 \\
\hline General care and management & $119(99.2)$ & $1(0.8)$ & 120 \\
\hline Improved breeding & $112(93.3)$ & $8(6.7)$ & 120 \\
\hline Castration & $116(96.7)$ & $4(3.3)$ & \\
\hline
\end{tabular}

Source: Field survey, 2008.

\section{Improved housing}

Housing has been identified to be one of the most important husbandry practices. Housing leads to decrease in theft and motor accident. It also helps to reduce the number of scavenging animals. In addition, confined animals are free from weather vagaries such scorching sun, beatings $b$ rain and dangerous winds and colds. This makes it easier to intervene in feeding, watering, health care and effective breeding. Under the improved housing system, farmers are encouraged to construct houses using their own designs however they must ensure that there is good ventilation for the animals. The houses should also be strong enough to understand the effects of weather vagaries such as rain, cold and wind.

Socio-economic characteristics such as number of goats, number of sheep, income from goats and farming experience were found not to show statistically significant relationship ( $p>0.05)$ with respect to adoption of improved housing (See Table 2 below). This implies that the number of sheep, number of goats, income from goats and farming experience do not influence adoption of innovations. However, socio-economic characteristics such as income from sheep, credit access, extension contact and farm education exposure were found to have significant relationship $(p<0.05)$ with adoption, implying these socio-economic characteristics influence adoption of innovations. This can be attributed to the fact that those who are able to earn substantial incomes from livestock attach more value to it, and therefore are more willing to adopt innovations that will enhance productivity. Access to credit provides farmers the ability to purchase basic drugs for treatment of animal diseases. Credit also enables farmers to provide better housing for animals. Extension services empower small ruminant farmers in terms of improved knowledge in animal production. The farmers explained that through extension services they are capable of providing 'good care' for their animals and to keep simple records on farm activities.

Table 2: Distribution of socio-economic characteristics and levels of adoption of improved housing

\begin{tabular}{|l|l|l|l|l|l|}
\hline \multicolumn{2}{|l|}{ Characteristics } & \multicolumn{2}{|l|}{$\begin{array}{l}\text { Level of adoption of improved } \\
\text { housing }\end{array}$} & $\begin{array}{l}\text { Test and } \\
\text { interpretation }\end{array}$ \\
\cline { 3 - 6 } & Adopted & $\begin{array}{l}\text { Not } \\
\text { adopted }\end{array}$ & Total & \\
\hline Number of & $<10$ & 10 & 33 & 43 & $\chi^{2}=0.781 \mathrm{df}=1$ \\
\hline
\end{tabular}




\begin{tabular}{|c|c|c|c|c|c|}
\hline \multirow[t]{2}{*}{ sheep kept } & $\geq 10$ & 19 & 42 & 61 & \multirow{2}{*}{$\begin{array}{l}0.4>p>0.3 \\
\text { Not significant }\end{array}$} \\
\hline & Total & 29 & 75 & 104 & \\
\hline \multirow{3}{*}{$\begin{array}{l}\text { Number of } \\
\text { goats kept }\end{array}$} & $<10$ & 17 & 44 & 61 & \multirow{3}{*}{$\begin{array}{l}\chi^{2}=0.004 \mathrm{df}=1 \\
1.0>p>0.9 \\
\text { Not significant }\end{array}$} \\
\hline & $\geq 10$ & 9 & 24 & 33 & \\
\hline & Total & 26 & 68 & 94 & \\
\hline \multirow{3}{*}{$\begin{array}{l}\text { Income from } \\
\text { sheep /year }\end{array}$} & $\leq 100$ (GHC) & 12 & 48 & 60 & \multirow{3}{*}{$\begin{array}{l}\chi^{2}=4.384 d f=1 \\
0.03<p<0.04 \\
\text { Significant }\end{array}$} \\
\hline & $>100$ (GHC) & 17 & 27 & 44 & \\
\hline & Total & 28 & 75 & 104 & \\
\hline \multirow{3}{*}{$\begin{array}{l}\text { Income from } \\
\text { goats/year }\end{array}$} & $\leq 50$ (GHC) & 16 & 34 & 50 & \multirow{3}{*}{$\begin{array}{l}\chi^{2}=1.006 \mathrm{df}=1 \\
0.4>p>0.3 \\
\text { Not significant }\end{array}$} \\
\hline & $>50(\mathrm{GHC})$ & 10 & 34 & 44 & \\
\hline & Total & 26 & 68 & 104 & \\
\hline \multirow[t]{3}{*}{ Credit access } & Yes & 6 & 4 & 10 & \multirow{3}{*}{$\begin{array}{l}\chi^{2}=6.647 \mathrm{df}=1 \\
0.02<p<0.01 \\
\text { Significant }\end{array}$} \\
\hline & No & 25 & 85 & 110 & \\
\hline & Total & 31 & 89 & 120 & \\
\hline \multirow{3}{*}{$\begin{array}{l}\text { Extension } \\
\text { contact }\end{array}$} & Never & 13 & 58 & 71 & \multirow{3}{*}{$\begin{array}{l}\chi^{2}=5.137 \mathrm{df}=1 \\
0.02<p<0.03 \\
\text { Significant }\end{array}$} \\
\hline & At least a month & 18 & 31 & 49 & \\
\hline & Total & 31 & 89 & 120 & \\
\hline \multirow{3}{*}{$\begin{array}{l}\text { Farming } \\
\text { experience }\end{array}$} & $<10$ years & 12 & 33 & 45 & \multirow{3}{*}{$\begin{array}{l}\chi^{2}=0.026 \mathrm{df}=1 \\
0.9>p>0.8 \\
\text { Not significant }\end{array}$} \\
\hline & $\geq 10$ years & 19 & 56 & 75 & \\
\hline & Total & 31 & 89 & 120 & \\
\hline \multirow{3}{*}{$\begin{array}{l}\text { Farm educ. } \\
\text { Exposure }\end{array}$} & Yes & 11 & 15 & 26 & \multirow{3}{*}{$\begin{array}{l}\chi^{2}=4.668 \mathrm{df}=1 \\
0.03<p<0.04 \\
\text { Significant }\end{array}$} \\
\hline & No & 20 & 74 & 94 & \\
\hline & Total & 31 & 89 & 120 & \\
\hline
\end{tabular}

Source: Field survey, 2008.

\section{Supplementary feeding}

Ruminants in Ghana are mainly produced in the range. Herbage growth on the range is dependent on rains. There are two peaks rainfall (March to August, September to December) in the forest belt and single peak (May to December) in the Savannah areas (MOFA, 2008). During the wet season livestock have little problem with feeding; however there is usually serious feed crisis during the dry periods which in turn affects production. Adequate supplementary feeding helps the animals to get the necessary nutrients for growth and for production all year round, and thus increase the incomes of farmers. As such farmers are trained and encouraged to feed their livestock with some selected feed resources such as crop residue (e.g. maize husk, maize chaff, rice straw, corn chaff and groundnut vines), agro by-products (e.g. yam peels, cassava peels, Pigeon pea waste).

Figures in Table 3 below indicate that the number of sheep, number of goats and sheep, income from goats, access to credit, farming experience and farm education exposure are not significant ( $p>0.05$ ) in explaining adoption of supplementary feeding. Extension contact showed a significant relationship $(0.02<p<0.03)$ with adoption of supplementary feeding. The implication is that extension contacts do influence adoption of supplementary feeding. Extension contacts probably create awareness and equip the people with more knowledge that help them to understand the technologies better and therefore are able to implement them easily. The findings are similar to that of Adesina and others of 2001 which found that the rate of adoption is higher among farmers who had contacts with extension agencies.

Table 3: Distribution of socio-economic characteristics and levels of adoption of supplementary feeding

\begin{tabular}{|l|l|l|}
\hline Characteristics & Level of adoption of supplementary & Test and \\
\hline
\end{tabular}




\begin{tabular}{|c|c|c|c|c|c|}
\hline & \multicolumn{3}{|l|}{ feeding } & \multirow[t]{2}{*}{ interpretation } \\
\hline & & Adopted & Not adopted & Total & \\
\hline \multirow{3}{*}{$\begin{array}{l}\text { Number of } \\
\text { sheep kept }\end{array}$} & $<10$ & 38 & 5 & 43 & \multirow{3}{*}{$\begin{array}{l}\chi^{2}=0.086 \mathrm{df}=1 \\
0.8>p>0.7 \\
\text { Not significant }\end{array}$} \\
\hline & $\geq 10$ & 55 & 6 & 61 & \\
\hline & Total & 93 & 11 & 104 & \\
\hline \multirow{3}{*}{$\begin{array}{l}\text { Number of } \\
\text { goats kept }\end{array}$} & $<10$ & 54 & 7 & 61 & \multirow{3}{*}{$\begin{array}{l}\chi^{2}=2.603 \mathrm{df}=1 \\
0.2>p>0.1 \\
\text { Not significan }\end{array}$} \\
\hline & $\geq 10$ & 25 & 8 & 33 & \\
\hline & Total & 79 & 15 & 94 & \\
\hline \multirow{3}{*}{$\begin{array}{l}\text { Income from } \\
\text { sheep }\end{array}$} & $\leq 100$ (GHC) & 52 & 8 & 60 & \multirow{3}{*}{$\begin{array}{l}\chi^{2}=1.139 \mathrm{df}=1 \\
0.3>p>0.2 \\
\text { Not significant }\end{array}$} \\
\hline & $>100$ (GHC) & 41 & 3 & 44 & \\
\hline & Total & 93 & 11 & 104 & \\
\hline \multirow{3}{*}{$\begin{array}{l}\text { Income from } \\
\text { goats }\end{array}$} & $\leq 50(\mathrm{GHC})$ & 42 & 8 & 50 & \multirow{3}{*}{$\begin{array}{l}\chi^{2}=0.000 \mathrm{df}=1 \\
1.0>p>0.9 \\
\text { Not significant }\end{array}$} \\
\hline & $>50(\mathrm{GHC})$ & 37 & 7 & 44 & \\
\hline & Total & 79 & 15 & 94 & \\
\hline \multirow[t]{3}{*}{ Credit access } & Yes & 9 & 1 & 10 & \multirow{3}{*}{$\begin{array}{l}\chi^{2}=0.156 \mathrm{df}=1 \\
0.7>p>0.6 \\
\text { Not significant }\end{array}$} \\
\hline & No & 94 & 16 & 110 & \\
\hline & Total & 103 & 17 & 120 & \\
\hline \multirow{3}{*}{$\begin{array}{l}\text { Extension } \\
\text { contact }\end{array}$} & Never & 57 & 14 & 71 & \multirow{3}{*}{$\begin{array}{l}\chi^{2}=4.407 \mathrm{df}=1 \\
0.03<p<0.04 \\
\text { Significant }\end{array}$} \\
\hline & At least a month & 46 & 3 & 49 & \\
\hline & Total & 103 & 17 & 120 & \\
\hline \multirow{3}{*}{$\begin{array}{l}\text { Farming } \\
\text { experience }\end{array}$} & $<10$ years & 42 & 3 & 45 & \multirow{3}{*}{$\begin{array}{l}\chi^{2}=3.331 \mathrm{df}=1 \\
0.07>p>0.06 \\
\text { Not significant }\end{array}$} \\
\hline & $\geq 10$ years & 61 & 14 & 75 & \\
\hline & Total & 103 & 17 & 120 & \\
\hline \multirow{3}{*}{$\begin{array}{l}\text { Farm educ. } \\
\text { Exposure }\end{array}$} & Yes & 22 & 4 & 26 & \multirow{3}{*}{$\begin{array}{l}\chi^{2}=0.040 \mathrm{df}=1 \\
0.9>p>0.8 \\
\text { Not significant }\end{array}$} \\
\hline & No & 81 & 13 & 94 & \\
\hline & Total & 103 & 17 & 120 & \\
\hline
\end{tabular}

Source: Field survey, 2008.

\section{Record keeping}

Record keeping improves farmer ability to determine breeding regimes and patterns. It also helps the farmer to determine the performance level of each animal and also to keep track of the ages of each animal for the purposes of health care, breeding, identification and marketing. Farmers are encouraged to keep records on birth and death, breeding, vaccination and marketing. The figures in Table 4 below show that socio-economic characteristics such as number of goats, number of sheep, income from goats and sheep, extension contacts, farming experience and farm education exposure had no significant relationship ( $p>0.05$ ) with adoption of record keeping. The findings are not in conformity with the hypothesis of Jatoe et al. (2005) that households with larger farm size are more likely to adopt new technologies. It also did not agree with Rahman's (2007) which found a significant relationship between farming experience and adoption of innovations. However, access to credit showed a significant relationship $(p<0.01)$ with adoption of record keeping, implying that credit access do influence adoption of innovations. Credit enables farmers to invest in animal housing and drugs as well as for meeting emergency expenditure on the upkeep of animals ${ }^{5}$.

Table 4: Distribution of socio-economic characteristics and level of adoption of record keeping

\begin{tabular}{|l|l|l|l|l|}
\hline \multirow{2}{*}{ Characteristics } & \multicolumn{2}{|l|}{ Level of adoption of record keeping } & $\begin{array}{l}\text { Test and } \\
\text { interpretation }\end{array}$ \\
\cline { 2 - 5 } & Adopt & Not adopted & Total & \\
\hline
\end{tabular}

\footnotetext{
${ }^{5}$ Record keeping in some instances can also assist farmers to acquire credit.
} 


\begin{tabular}{|c|c|c|c|c|c|}
\hline & & ed & & & \\
\hline \multirow{3}{*}{$\begin{array}{l}\text { Number of } \\
\text { sheep kept }\end{array}$} & $<10$ & 7 & 36 & 43 & \multirow{3}{*}{$\begin{array}{l}\chi^{2}=0.411 \mathrm{df}=1 \\
0.6>p>0.5 \\
\text { Not significant }\end{array}$} \\
\hline & $\geq 10$ & 13 & 48 & 61 & \\
\hline & Total & 20 & 84 & 104 & \\
\hline \multirow{3}{*}{$\begin{array}{l}\text { Number of } \\
\text { goats kept }\end{array}$} & $<10$ & 12 & 49 & 61 & \multirow{3}{*}{$\begin{array}{l}\chi^{2}=0.295 \mathrm{df}=1 \\
0.6>p>0.5 \\
\text { Not significant }\end{array}$} \\
\hline & $\geq 10$ & 5 & 28 & 33 & \\
\hline & Total & 17 & 97 & 94 & \\
\hline \multirow{3}{*}{$\begin{array}{l}\text { Income from } \\
\text { sheep }\end{array}$} & $\leq 100$ (GHC) & 11 & 49 & 60 & \multirow{3}{*}{$\begin{array}{l}\chi^{2}=0.74 d f=1 \\
0.8>p>0.7 \\
\text { Not significant }\end{array}$} \\
\hline & $>100$ (GHC) & 9 & 35 & 44 & \\
\hline & Total & 20 & 84 & 104 & \\
\hline \multirow{3}{*}{$\begin{array}{l}\text { Income from } \\
\text { goats }\end{array}$} & $\leq 50$ (GHC) & 12 & 38 & 50 & \multirow{3}{*}{$\begin{array}{l}\chi^{2}=2.523 \mathrm{df}=1 \\
0.2>p>0.1 \\
\text { Not significant }\end{array}$} \\
\hline & $>50(\mathrm{GHC})$ & 5 & 39 & 44 & \\
\hline & Total & 17 & 77 & 94 & \\
\hline \multirow[t]{3}{*}{ Credit access } & Yes & 6 & 4 & 10 & \multirow{3}{*}{$\begin{array}{l}\chi^{2}=12.650 \mathrm{df}=1 \\
0.001<p<0.002 \\
\text { Significant }\end{array}$} \\
\hline & No & 16 & 94 & 110 & \\
\hline & Total & 22 & 98 & 120 & \\
\hline \multirow{3}{*}{$\begin{array}{l}\text { Extension } \\
\text { contact }\end{array}$} & Never & 11 & 60 & 71 & \multirow{3}{*}{$\begin{array}{l}\chi^{2}=0.937 \mathrm{df}=1 \\
0.4>p>0.3 \\
\text { Not significant }\end{array}$} \\
\hline & $\begin{array}{l}\text { At least a } \\
\text { month }\end{array}$ & 11 & 38 & 49 & \\
\hline & Total & 22 & 98 & 120 & \\
\hline \multirow{3}{*}{$\begin{array}{l}\text { Farming } \\
\text { experience }\end{array}$} & $<10$ years & 8 & 37 & 45 & \multirow{3}{*}{$\begin{array}{l}\chi^{2}=0.015 \mathrm{df}=1 \\
0.10>p>0.09 \\
\text { Not significant }\end{array}$} \\
\hline & $\geq 10$ years & 14 & 61 & 75 & \\
\hline & Total & 22 & 98 & 120 & \\
\hline \multirow{3}{*}{$\begin{array}{l}\text { Farm educ. } \\
\text { Exposure }\end{array}$} & Yes & 13 & 13 & 26 & \multirow{3}{*}{$\begin{array}{l}\chi^{2}=2.213 \mathrm{df}=1 \\
0.2>p>0.1 \\
\text { Not significant }\end{array}$} \\
\hline & No & 32 & 62 & 94 & \\
\hline & Total & 45 & 75 & 120 & \\
\hline
\end{tabular}

Source: Field survey, 2008.

\section{Forage preservation and utilization}

Forage preservation and utilization helps farmers to get balanced rations for their livestock throughout the year. Under forage preservation and utilization, farmers are encouraged to dry and store feed resources such as crop residue and agro by product. Farmers are also encouraged to institute fodder banks by planting some leguminous plants and to use them to feed their livestock. In addition to these farmers are also encouraged to treat their crop residue especially rice straw with urea in order to increase their nutrient content.

Extension contact was found to have a significant relationship $(p<0.01)$ with respect to adoption of forage preservation and utilization (See Table 5 below). All other socio-economic characteristics considered did not show a significant relationship $(p>0.05)$. The implication is that extension contacts do influence level of adoption of forage preservation and utilization. Thus, through extension contact, farmers are able to understand, preserve and use forage well. Also regular contacts with extension staff could serve as source of motivation to the people, and therefore influence their decision to adopt innovation.

Table 5: Distribution of socio-economic characteristics and level of adoption of forage preservation and utilization

\begin{tabular}{|l|l|l|l|l|}
\hline Characteristics & \multicolumn{2}{|l|}{$\begin{array}{l}\text { Level of adoption of forage } \\
\text { preservation and utilization }\end{array}$} & $\begin{array}{l}\text { Test and } \\
\text { interpretation }\end{array}$ \\
\cline { 2 - 3 } & Adopted & Not & Total & \\
\hline
\end{tabular}




\begin{tabular}{|c|c|c|c|c|c|}
\hline & & & adopted & & \\
\hline \multirow{3}{*}{$\begin{array}{l}\text { Number of sheep } \\
\text { kept }\end{array}$} & $<10$ & 20 & 23 & 43 & \multirow{3}{*}{$\begin{array}{l}\chi^{2}=0.531 \mathrm{df}=1 \\
0.5>p>0.4 \\
\text { Not significant }\end{array}$} \\
\hline & $\geq 10$ & 24 & 37 & 61 & \\
\hline & Total & 44 & 60 & 104 & \\
\hline \multirow{3}{*}{$\begin{array}{l}\text { Number of goats } \\
\text { kept }\end{array}$} & $<10$ & 24 & 37 & 61 & \multirow{3}{*}{$\begin{array}{l}\chi^{2}=1.370 \mathrm{df}=1 \\
0.3>p>0.2 \\
\text { Not significant }\end{array}$} \\
\hline & $\geq 10$ & 9 & 24 & 33 & \\
\hline & Total & 33 & 61 & 94 & \\
\hline \multirow[t]{3}{*}{ Income from sheep } & $\leq 100(\mathrm{GHC})$ & 23 & 37 & 60 & \multirow{3}{*}{$\begin{array}{l}\chi^{2}=0.918 \mathrm{df}=1 \\
0.4>p>0.3 \\
\text { Not significant }\end{array}$} \\
\hline & $>100(\mathrm{GHC})$ & 21 & 23 & 44 & \\
\hline & Total & 44 & 60 & 104 & \\
\hline \multirow[t]{3}{*}{ Income from goats } & $\leq 50(\mathrm{GHC})$ & 15 & 35 & 50 & \multirow{3}{*}{$\begin{array}{l}\chi^{2}=1.223 \mathrm{df}=1 \\
0.3>p>0.2 \\
\text { Not significant }\end{array}$} \\
\hline & $>50(\mathrm{GHC})$ & 18 & 26 & 44 & \\
\hline & Total & 33 & 61 & 94 & \\
\hline \multirow[t]{3}{*}{ Credit access } & Yes & 9 & 1 & 10 & \multirow{3}{*}{$\begin{array}{l}\chi^{2}=0.156 \mathrm{df}=1 \\
0.7>p>0.6 \\
\text { Not significant }\end{array}$} \\
\hline & No & 94 & 16 & 110 & \\
\hline & Total & 103 & 17 & 120 & \\
\hline \multirow[t]{3}{*}{ Extension contact } & Never & 16 & 55 & 71 & \multirow{3}{*}{$\begin{array}{l}\chi^{2}=16.614 d f=1 \\
0.001<p<0.002 \\
\text { Significant }\end{array}$} \\
\hline & $\begin{array}{l}\text { At least a } \\
\text { month }\end{array}$ & 29 & 20 & 49 & \\
\hline & Total & 45 & 75 & 120 & \\
\hline \multirow[t]{3}{*}{ Farming experience } & $<10$ years & 42 & 3 & 45 & \multirow{3}{*}{$\begin{array}{l}\chi^{2}=3.331 \mathrm{df}=1 \\
0.07>p>0.06 \\
\text { Not significant }\end{array}$} \\
\hline & $\geq 10$ years & 61 & 14 & 75 & \\
\hline & Total & 103 & 17 & 120 & \\
\hline \multirow{3}{*}{$\begin{array}{l}\text { Farm educ. } \\
\text { Exposure }\end{array}$} & Yes & 13 & 13 & 26 & \multirow{3}{*}{$\begin{array}{l}\chi^{2}=2.213 \mathrm{df}=1 \\
0.2>p>0.1 \\
\text { Not significant }\end{array}$} \\
\hline & No & 32 & 62 & 94 & \\
\hline & Total & 45 & 75 & 120 & \\
\hline
\end{tabular}

Source: Field survey, 2008.

\section{Prophylactic treatment}

Prophylactic treatment helps to prevent animals from disease infection. It also leads to improved health care and hence an increase in livestock population and consumption of healthy meat. Small ruminant farmers in the Northern region tend to lose some of animals to pest and diseases. The unwillingness of farmers to provide health care to these animals is the main cause of it. In view of that, farmers are encouraged to regularly vaccinate their animals against preventable diseases such as anthrax and Pestes des petite ruminants (PPR) yearly to prevent their livestock from being wiped off during periods of epidemics. Also, they are expected to regularly de-worm and de-tick their animals to prevent them from infestation. To ensure that farmers in the communities had access to some prophylactic treatment, some community members known as the 'community livestock workers' are given some training on some basic skills in de-worming and de-ticking to be able to render services to colleagues to reduce the impact of disease infection.

As shown in Table 6, apart from extension contact and farming experience which showed significant relationship $(p<0.05)$ with adoption of prophylactic treatment, the rest did not exhibit any significant relationship ( $p>0.05$ ). The implication is that socio-economic characteristics such as extension contact and farming experience do influence adoption of prophylactic treatment. The findings agree 
with that of Adesina et al (2001) that the rate of adoption is higher among farmers who had contacts with extension agencies.

Table 6: Distribution of socio-economic characteristics and level of adoption of prophylactic treatment

\begin{tabular}{|c|c|c|c|c|c|}
\hline \multirow{2}{*}{\multicolumn{2}{|c|}{ Characteristics }} & \multicolumn{3}{|c|}{$\begin{array}{l}\text { Level of adoption of prophylactic } \\
\text { treatment }\end{array}$} & \multirow[t]{2}{*}{$\begin{array}{l}\text { Test and } \\
\text { interpretation }\end{array}$} \\
\hline & & Adopted & Not adopted & Total & \\
\hline \multirow{3}{*}{$\begin{array}{l}\text { Number of } \\
\text { sheep kept }\end{array}$} & $<10$ & 32 & 11 & 43 & \multirow{3}{*}{$\begin{array}{l}\chi^{2}=0.862 \mathrm{df}=1 \\
0.4>p>0.3 \\
\text { Not significant }\end{array}$} \\
\hline & $\geq 10$ & 50 & 11 & 61 & \\
\hline & Total & 50 & 22 & 104 & \\
\hline \multirow{3}{*}{$\begin{array}{l}\text { Number of } \\
\text { goats kept }\end{array}$} & $<10$ & 46 & 15 & 61 & \multirow{3}{*}{$\begin{array}{l}\chi^{2}=0.136 \mathrm{df}=1 \\
0.8>p>0.7 \\
\text { Not significant }\end{array}$} \\
\hline & $\geq 10$ & 26 & 7 & 33 & \\
\hline & Total & 72 & 22 & 94 & \\
\hline \multirow{3}{*}{$\begin{array}{l}\text { Income from } \\
\text { sheep }\end{array}$} & $\leq 100$ (GHC) & 44 & 16 & 60 & \multirow{3}{*}{$\begin{array}{l}\chi^{2}=2.584 \mathrm{df}=1 \\
0.2>p>0.1 \\
\text { Not significant }\end{array}$} \\
\hline & $>100(\mathrm{GHC})$ & 38 & 6 & 44 & \\
\hline & Total & 82 & 22 & 104 & \\
\hline \multirow{3}{*}{$\begin{array}{l}\text { Income from } \\
\text { goats }\end{array}$} & $\leq 50(\mathrm{GHC})$ & 37 & 13 & 50 & \multirow{3}{*}{$\begin{array}{l}\chi^{2}=0.401 \mathrm{df}=1 \\
0.6>p>0.5 \\
\text { Not significant }\end{array}$} \\
\hline & $>50(\mathrm{GHC})$ & 35 & 9 & 44 & \\
\hline & Total & 72 & 22 & 94 & \\
\hline \multirow[t]{3}{*}{ Credit access } & Yes & 10 & 0 & 10 & \multirow{3}{*}{$\begin{array}{l}\chi^{2}=2.871 \mathrm{df}=1 \\
0.09>p>0.08 \\
\text { Not significant }\end{array}$} \\
\hline & No & 85 & 25 & 110 & \\
\hline & Total & 95 & 25 & 120 & \\
\hline \multirow{3}{*}{$\begin{array}{l}\text { Extension } \\
\text { contact }\end{array}$} & Never & 50 & 21 & 71 & \multirow{3}{*}{$\begin{array}{l}\chi^{2}=8.061 \mathrm{df}=1 \\
0.005<p<0.006 \\
\text { Significant }\end{array}$} \\
\hline & $\begin{array}{l}\text { At least a } \\
\text { month }\end{array}$ & 45 & 4 & 49 & \\
\hline & Total & 95 & 25 & 120 & \\
\hline \multirow{3}{*}{$\begin{array}{l}\text { Farming } \\
\text { experience }\end{array}$} & $<10$ years & 40 & 5 & 45 & \multirow{3}{*}{$\begin{array}{l}\chi^{2}=4.126 \mathrm{df}=1 \\
0.04<p<0.05 \\
\text { Significant }\end{array}$} \\
\hline & $\geq 10$ years & 55 & 20 & 75 & \\
\hline & Total & 95 & 25 & 120 & \\
\hline \multirow{3}{*}{$\begin{array}{l}\text { Farm educ. } \\
\text { Exposure }\end{array}$} & Yes & 23 & 3 & 26 & \multirow{3}{*}{$\begin{array}{l}\chi^{2}=1.739 \mathrm{df}=1 \\
0.187>p>0.186 \\
\text { Not significant }\end{array}$} \\
\hline & No & 72 & 22 & 94 & \\
\hline & Total & 95 & 25 & 120 & \\
\hline
\end{tabular}

Source: Field survey, 2008.

\section{General care and management}

General care and management helps to ensure healthy living of the animals and increase production. Under the general care and management, farmers are encouraged to ensure the good sanitation of their flocks by regularly cleaning the farm house and bathing the animals, especially sheep, occasionally. They are also encouraged to feed and water the animals regularly, trim their hooves when they are overgrown, house them properly, regularly provide health care and generally respect the right of the animals.

Apart from extension contact which exhibited a significant relationship $(0.005<p<0.006)$ with the adoption of general care and management, the rest of the socio-economic characteristics never showed any significant relationship $(p>0.05)$ with respect to general care and management. The implication is that extension contacts do influence adoption of general care and management. These findings could be ascribed to the fact that extension contacts help the farmers to understand and 
appreciate the importance of the innovations. Also, extension officer contacts with farmers motivate them to pay greater attention to issues that help improve their farming practices.

Table 7: Distribution of socio-economic characteristics and level of adoption of general care and management

\begin{tabular}{|c|c|c|c|c|c|}
\hline \multicolumn{2}{|c|}{ Characteristics } & \multicolumn{3}{|c|}{$\begin{array}{l}\text { Level of adoption of general care } \\
\text { and management }\end{array}$} & \multirow[t]{2}{*}{$\begin{array}{l}\text { Test and } \\
\text { interpretation }\end{array}$} \\
\hline & & Adopted & $\begin{array}{l}\text { Not } \\
\text { adopted }\end{array}$ & Total & \\
\hline \multirow{3}{*}{$\begin{array}{l}\text { Number of } \\
\text { sheep kept }\end{array}$} & $<10$ & 30 & 13 & 43 & \multirow{3}{*}{$\begin{array}{l}\chi^{2}=1.540 \mathrm{df}=1 \\
0.3>p>0.2 \\
\text { Not significant }\end{array}$} \\
\hline & $\geq 10$ & 49 & 12 & 61 & \\
\hline & Total & 79 & 25 & 104 & \\
\hline \multirow{3}{*}{$\begin{array}{l}\text { Number of } \\
\text { goats kept }\end{array}$} & $<10$ & 45 & 16 & 61 & \multirow{3}{*}{$\begin{array}{l}\chi^{2}=0.178 \mathrm{df}=1 \\
0.7>p>0.6 \\
\text { Not significant }\end{array}$} \\
\hline & $\geq 10$ & 23 & 10 & 33 & \\
\hline & Total & 68 & 26 & 94 & \\
\hline \multirow{3}{*}{$\begin{array}{l}\text { Income from } \\
\text { sheep }\end{array}$} & $\leq 100$ (GHC) & 41 & 19 & 60 & \multirow{3}{*}{$\begin{array}{l}\chi^{2}=4.519 d f=1 \\
0.03<p<0.04 \\
\text { Significant }\end{array}$} \\
\hline & $>100$ (GHC) & 38 & 6 & 44 & \\
\hline & Total & 79 & 25 & 104 & \\
\hline \multirow{3}{*}{$\begin{array}{l}\text { Income from } \\
\text { goats }\end{array}$} & $\leq 50(\mathrm{GHC})$ & 36 & 14 & 50 & \multirow{3}{*}{$\begin{array}{l}\chi^{2}=0.006 \mathrm{df}=1 \\
1.0>p>0.9 \\
\text { Not significant }\end{array}$} \\
\hline & $>50(\mathrm{GHC})$ & 32 & 12 & 44 & \\
\hline & Total & 68 & 26 & 94 & \\
\hline \multirow[t]{3}{*}{ Credit access } & Yes & 9 & 1 & 10 & \multirow{3}{*}{$\begin{array}{l}\chi^{2}=1.309 \mathrm{df}=1 \\
0.3>p>0.2 \\
\text { Not significant }\end{array}$} \\
\hline & No & 81 & 29 & 110 & \\
\hline & Total & 90 & 30 & 120 & \\
\hline \multirow{3}{*}{$\begin{array}{l}\text { Extension } \\
\text { contact }\end{array}$} & Never & 50 & 21 & 71 & \multirow{3}{*}{$\begin{array}{l}\chi^{2}=8.061 \mathrm{df}=1 \\
0.005<p<0.006 \\
\text { Significant }\end{array}$} \\
\hline & At least a month & 45 & 4 & 49 & \\
\hline & Total & 95 & 25 & 120 & \\
\hline \multirow{3}{*}{$\begin{array}{l}\text { Farming } \\
\text { experience }\end{array}$} & $<10$ years & 37 & 8 & 45 & \multirow{3}{*}{$\begin{array}{l}\chi^{2}=2.003 \mathrm{df}=1 \\
0.2>p>0.1 \\
\text { Not significant }\end{array}$} \\
\hline & $\geq 10$ years & 53 & 22 & 75 & \\
\hline & Total & 90 & 30 & 120 & \\
\hline \multirow{3}{*}{$\begin{array}{l}\text { Farm educ. } \\
\text { Exposure }\end{array}$} & Yes & 23 & 3 & 26 & \multirow{3}{*}{$\begin{array}{l}\chi^{2}=3.208 \mathrm{df}=1 \\
0.08>p>0.07 \\
\text { Not significant }\end{array}$} \\
\hline & No & 67 & 27 & 94 & \\
\hline & Total & 90 & 30 & 120 & \\
\hline
\end{tabular}

Source: Field survey, 2008.

\section{Castration}

Castration helps to prevent inbreeding, eliminate undesirable characters from a flock and fatten the animals for good market. Under the castration farmers are encouraged to castrate all the non breeding male animals and allow them to grow well for better market. To ensure that farmers have access to castration, some community members known as 'community livestock workers' are trained to be able to carry out closed castration in their respective communities. As indicated in Table 8 below, none of the socio-economic characteristics considered exhibited any significant relationship $(p>0.05)$ with respect to adoption of castration. This implies that socio-economic characteristics do not influence adoption of castration. Most of the respondents did not castrate their sheep because they did not use castrated sheep for naming ceremonies and Moslem sacrifice; and therefore were afraid of not accessing the dominant local market for livestock, since they rely heavily on the local market. Further, most respondents explained that a castrated animal takes more time to mature, and therefore cannot be sold immediately when they need cash. 
Table 1: Distribution of socio-economic characteristics and level of adoption of castration

\begin{tabular}{|c|c|c|c|c|c|}
\hline \multirow{2}{*}{\multicolumn{2}{|c|}{ Characteristics }} & \multirow{2}{*}{\multicolumn{3}{|c|}{ Level of adoption of castration }} & \multirow{5}{*}{$\begin{array}{l}\begin{array}{l}\text { Test and } \\
\text { interpretation }\end{array} \\
\chi^{2}=0.136 \mathrm{df}=1 \\
0.8>p>0.7 \\
\text { Not significant }\end{array}$} \\
\hline & & & & \multirow{2}{*}{$\begin{array}{l}\text { Total } \\
43\end{array}$} & \\
\hline \multirow{3}{*}{$\begin{array}{l}\text { Number of sheep } \\
\text { kept }\end{array}$} & $<10$ & \multirow{2}{*}{\begin{tabular}{|l|} 
Adopted \\
9 \\
11
\end{tabular}} & $\begin{array}{l}\text { Not } \\
\text { adopted } \\
34\end{array}$ & & \\
\hline & $\geq 10$ & & 50 & 61 & \\
\hline & Total & 20 & 84 & 104 & \\
\hline \multirow{3}{*}{$\begin{array}{l}\text { Number of goats } \\
\text { kept }\end{array}$} & $<10$ & 13 & 48 & 61 & \multirow{3}{*}{$\begin{array}{l}\chi^{2}=1.628 \mathrm{df}=1 \\
0.3>p>0.2 \\
\text { Not significant }\end{array}$} \\
\hline & $\geq 10$ & 11 & 22 & 33 & \\
\hline & Total & 24 & 70 & 94 & \\
\hline \multirow{3}{*}{$\begin{array}{l}\text { Income from } \\
\text { sheep }\end{array}$} & $\leq 100$ (GHC) & 10 & 50 & 60 & \multirow{3}{*}{$\begin{array}{l}\chi^{2}=0.600 \mathrm{df}=1 \\
0.5>p>0.4 \\
\text { Not significant }\end{array}$} \\
\hline & $>100(\mathrm{GHC})$ & 10 & 34 & 44 & \\
\hline & Total & 20 & 84 & 104 & \\
\hline \multirow{3}{*}{$\begin{array}{l}\text { Income from } \\
\text { goats }\end{array}$} & $\leq 50$ (GHC) & 12 & 38 & 50 & \multirow{3}{*}{$\begin{array}{l}\chi^{2}=0.132 \mathrm{df}=1 \\
0.8>p>0.7 \\
\text { Not significant }\end{array}$} \\
\hline & $>50(\mathrm{GHC})$ & 12 & 32 & 44 & \\
\hline & Total & 24 & 70 & 104 & \\
\hline \multirow[t]{3}{*}{ Credit access } & Yes & 1 & 9 & 10 & \multirow{3}{*}{$\begin{array}{l}\chi^{2}=0.776 \mathrm{df}=1 \\
0.4>p>0.3 \\
\text { Not significant }\end{array}$} \\
\hline & No & 24 & 86 & 110 & \\
\hline & Total & 26 & 95 & 120 & \\
\hline \multirow[t]{3}{*}{ Extension contact } & Never & 15 & 56 & 71 & \multirow{3}{*}{$\begin{array}{l}\chi^{2}=0.009 \mathrm{df}=1 \\
0.924>p>0.923 \\
\text { Not significant }\end{array}$} \\
\hline & At least a month & 10 & 39 & 49 & \\
\hline & Total & 25 & 95 & 120 & \\
\hline \multirow{3}{*}{$\begin{array}{l}\text { Farming } \\
\text { experience }\end{array}$} & $<10$ years & 11 & 34 & 45 & \multirow{3}{*}{$\begin{array}{l}\chi^{2}=0.569 \mathrm{df}=1 \\
0.5>p>0.4 \\
\text { Not significant }\end{array}$} \\
\hline & $\geq 10$ years & 14 & 61 & 75 & \\
\hline & Total & 25 & 95 & 120 & \\
\hline \multirow{3}{*}{$\begin{array}{l}\text { Farm educ. } \\
\text { Exposure }\end{array}$} & Yes & 8 & 18 & 26 & \multirow{3}{*}{$\begin{array}{l}\chi^{2}=1.987 \mathrm{df}=1 \\
0.2>p>0.1 \\
\text { Not significant }\end{array}$} \\
\hline & No & 17 & 77 & 94 & \\
\hline & Total & 25 & 95 & 120 & \\
\hline
\end{tabular}

Source: Field survey, 2008.

\section{Improved breeding}

Improved breeds are relatively bigger and thus have good market value. Also, they are more resistant to diseases. Farmers were found to be breeding the local ones which had relatively smaller body size and thus do not attract good market. Therefore, the livestock policy programs offered an improved breeding system. Under the improved breeding system, farmers are encouraged to cross the Djallonke with the Sahelian sheep, and also to cross the West African Dwarf and Sahelian goats to obtain a hybrid with advantageous characteristics. The selection of good ones among the local breeds for breeding has also been encouraged. To ensure that farmers got access to these improved breeds, some farmers were selected under the nuclear breeding program to represent the breeding stations and to breed the improved breeds for sale to other farmers. Cattle, sheep, goats, pigs, rabbits and grasscutters breeding were intensified under NLSP. Essentially, it involved the genetic improvement of the livestock using the open nucleus breeding scheme (ONBS) and the improvement of the numerical count of population of various livestock using the out breaker scheme.

Figures in Table 9 indicate that socio-economic characteristics such as number of sheep and farm education exposure have significant relationship $(p<0.05)$ with respect to adoption of improved breeding. The implication is that the number of sheep and farm education exposure do influence adoption of improved breeding. Those who have access to farm education gain more experience and tend to appreciate the importance of improved breeds. The findings agree with Rahman (2007) who 
found a positive and significant relationship with respect to farm education exposure and adoption of improved technologies.

Table 2: Distribution of socio-economic characteristics and level of adoption of improved breeding

\begin{tabular}{|c|c|c|c|c|c|}
\hline \multirow{2}{*}{\multicolumn{2}{|c|}{ Characteristics }} & \multicolumn{3}{|c|}{$\begin{array}{l}\text { Level of adoption of improved } \\
\text { breeding }\end{array}$} & \multirow[t]{2}{*}{$\begin{array}{l}\text { Test and } \\
\text { interpretation }\end{array}$} \\
\hline & & Adopted & $\begin{array}{l}\text { Not } \\
\text { adopted }\end{array}$ & Total & \\
\hline \multirow{3}{*}{$\begin{array}{l}\text { Number of sheep } \\
\text { kept }\end{array}$} & $<10$ & 2 & 41 & 43 & \multirow{3}{*}{$\begin{array}{l}\chi^{2}=0.505 \mathrm{df}=1 \\
0.5>p>0.4 \\
\text { Not significant }\end{array}$} \\
\hline & $\geq 10$ & 5 & 56 & 61 & \\
\hline & Total & 7 & 97 & 104 & \\
\hline \multirow{3}{*}{$\begin{array}{l}\text { Number of goats } \\
\text { kept }\end{array}$} & $<10$ & 2 & 59 & 61 & \multirow{3}{*}{$\begin{array}{l}\chi^{2}=6.109 \mathrm{df}=1 \\
0.02<p<0.01 \\
\text { Significant }\end{array}$} \\
\hline & $\geq 10$ & 6 & 27 & 33 & \\
\hline & Total & 8 & 86 & 94 & \\
\hline \multirow{3}{*}{$\begin{array}{l}\text { Income from } \\
\text { sheep }\end{array}$} & $\leq 100(\mathrm{GHC})$ & 3 & 57 & 60 & \multirow{3}{*}{$\begin{array}{l}\chi^{2}=0.688 \mathrm{df}=1 \\
0.5>p>0.4 \\
\text { Not significant }\end{array}$} \\
\hline & $>100(\mathrm{GHC})$ & 4 & 40 & 44 & \\
\hline & Total & 7 & 97 & 104 & \\
\hline \multirow{3}{*}{$\begin{array}{l}\text { Income from } \\
\text { goats }\end{array}$} & $\leq 50(\mathrm{GHC})$ & 3 & 47 & 50 & \multirow{3}{*}{$\begin{array}{l}\chi^{2}=0.865 \mathrm{df}=1 \\
0.4>p>0.3 \\
\text { Not significant }\end{array}$} \\
\hline & $>50$ (GHC) & 5 & 39 & 44 & \\
\hline & Total & 8 & 86 & 94 & \\
\hline \multirow[t]{3}{*}{ Credit access } & Yes & 1 & 9 & 10 & \multirow{3}{*}{$\begin{array}{l}\chi^{2}=0.195 \mathrm{df}=1 \\
0.7>p>0.6 \\
\text { Not significant }\end{array}$} \\
\hline & No & 7 & 103 & 110 & \\
\hline & Total & 8 & 112 & 120 & \\
\hline \multirow[t]{3}{*}{ Extension contact } & Never & 4 & 67 & 71 & \multirow{3}{*}{$\begin{array}{l}\chi^{2}=0.298 \mathrm{df}=1 \\
0.6>p>0.5 \\
\text { Not significant }\end{array}$} \\
\hline & At least a month & 4 & 45 & 49 & \\
\hline & Total & 8 & 112 & 120 & \\
\hline \multirow{3}{*}{$\begin{array}{l}\text { Farming } \\
\text { experience }\end{array}$} & $<10$ years & 11 & 34 & 45 & \multirow{3}{*}{$\begin{array}{l}\chi^{2}=0.596 \mathrm{df}=1 \\
0.5>p>0.4 \\
\text { Not significant }\end{array}$} \\
\hline & $\geq 10$ years & 14 & 61 & 75 & \\
\hline & Total & 25 & 95 & 120 & \\
\hline \multirow{3}{*}{$\begin{array}{l}\text { Farm educ. } \\
\text { Exposure }\end{array}$} & Yes & 5 & 21 & 26 & \multirow{3}{*}{$\begin{array}{l}\chi^{2}=8.421 \mathrm{df}=1 \\
0.004<p<0.005 \\
\text { Significant }\end{array}$} \\
\hline & No & 3 & 91 & 94 & \\
\hline & Total & 8 & 112 & 112 & \\
\hline
\end{tabular}

Source: Field survey, 2008.

\section{CONCLUSIONS}

The present study was undertaken to assess the extent to which innovations introduced to the farmers in the study area are adopted and to determine the factors which influence adoption of small ruminants' innovations. The results show that poor husbandry practices affect small ruminant production in the Tolon-Kumbungu district. This is partly caused by lack of adoption of innovations; and innovations have to be adopted to ensure high productivity. The study also revealed that some socio-economic factors do influence the adoption of small ruminant innovations. Particularly, credit access, extension contact and farm education exposure significantly explain adoption of improved housing. Further, credit accessibility is significant for the adoption of record keeping. Extension contact does influence adoption of forage preservation and utilization. Both extension contact and farming experience are significant in terms of adoption of prophylactic treatment. Extension contact and income from sheep do influence adoption of general care and management. In addition, both extension contact and access to credit influence adoption of tagging. The number of goats and farm education exposure do influence adoption of improved breeding. Costs of innovation, selective contacts by extension agents, lack of sufficient knowledge of the innovations, contradiction of 
innovations with certain parts of culture were some of the limiting factors to adoption of innovations.

\section{POLICY RECOMMENDATIONS}

Extension contact was significant with respect to most of the innovations. This shows that there is a strong link between extension contact and level of adoption of innovations. Farmers who have regular extension contact have constant solutions to their problems compared with those farmers without regular visits. Unfortunately, the whole study area lacks a livestock production expert. Therefore, the study recommends that more Agricultural Extension Staff be trained by government to fill numerous vacancies in the area.

Access to credit helps farmers to increase small ruminants' production and those who received some form of credit had high adoption of the innovations as compared to others without credit. Small ruminant farmers who had access to credit complained of high interest rates. The study therefore recommends that steps be taken by government to make credit source available, accessible and affordable to farmers.

\section{REFERENCES}

Adama-Mohammed, Janet and Agnes A. Apusigah (2005). "Baseline Study on Human Trafficking and Forced Labour in northern Ghana." A Report submitted to the International Labour Organization, Geneva, Sweden and Ghana (unpublished).

Adesina A.A., Mbila D., Nkamleu G.B. \& Endamana D. (2001). Econometric analysis of the determinants of adoption of alley farming by farmers in the forest zone of southwest Cameroon. Agriculture, Ecosystems and Environment 80:255-265.

Agtax,Wren (1996). Taking goat for granted. In Ghanaian Times. January 16, 1996, pp 6.

Ajala M. K. (2004). Household decision-making in the production of small ruminants in Giwa Local Government Area of Kaduna State of Nigeria. In: Proceedings of the $29^{\text {th }}$ Annual Conference of the Nigerian Society of Animal Production, $21^{\text {st }}-25^{\text {th }}$ March, 2004. Sokoto, Nigeria. Pp 399-402.

Feder, G., Just R.E., \& Zilberman D. (1982). Adoption of agricultural innovations in developing countries: A study. World Bank Staff. Working paper, 542.

Dei H.K., Konadu K.O, Otchere E.O. \& Djang-Fordjour K.T. (2007). Housing of small ruminants in the Tolon-Kumbungu district of the northern region of Ghana. Proceedings of the fifteenth Biennial Conference .KNUST-Kumasi pp. 85-88.

Harrison, R.E. (1986). The role of improved pastures in commercial production in the tropics and sub-tropics (The Harry Stobbs memorial lecture for 1985) Trop. Grasslands 20(2), 3-17.

Huq, M. M. (1989). The economy of Ghana. The first 29 years after independence. Ghana. Macmillan press Ltd.

Institute for Social, Statistics, and Economic Research (2004). The state of Ghanaian economy in 2003. Accra. University of Ghana.

Institute for Social, Statistics, and Economic Research (2006). The state of Ghanaian economy in 
2005. University of Ghana. Pp106-130.

Jabbar, M. A. (1990). Socio-economic aspects of diffusion and adoption of alley farming. Paper presented at Alley Farming training Course, IITA, Ibadan, Nigeria. P. 6-10.

Jatoe, J B D, Al-Hassan, R M and Abatania, L N. 2005. Factors Affecting the Adoption of Improved Sorghum Varieties among Farm Households in Northwest Ghana: A Probit Analysis", Ghana Journal of Development Studies, Volume 2, Number 1. Pp 37- 50.

Koney, E.M.B. (1992). Livestock Production and health in Ghana. Advent Press, Accra Ghana.

Kinnucan, H., Hatch, U., Molnar, J., \& Pendergrass, R. (1990). Adoption and diffusion potentials for bovine somatotropin in Southeast dairy industry. Bulletin 605. Auburn University, Alabama, USA.

Latoper, U. (2001). Livestock production systems in urban and peri-urban areas of Tamale. B.Sc. (Agric Tech.) Dissertation, University for Development studies, Tamale.

LDP (2003). Project document. Ministry of Food and Agriculture, Ghana.

MOFA (2007). Annual report. Accra, Ghana.

Ogunlana, E.A. (2003). The Technology Adoption of Women Farmers: The case of alley farming in Nigeria. DA: $5^{\text {th }}$ August, 2008. Available: http://www.journals.

Cambridge.org/download.php?file=\%2FRAF\%2FRAF.

Rahman, S (2007). Adoption of improved technologies by pig farmers of Aizawl district of Mizoran,India. Department of veterinary and Animal Husbandry Extension, College of Veterinary Sciences and Animal Husbandry, Central Agriculture University, Selesih, Aizawl, Mizoram-796014, India: Pp 1-10.

Rogers, E. (2003). Diffusion of innovations. The Free Press, New York.

Sheth, J.N., Mittal, B., and Newman, B. I. 1999. Customer Behavior: Consumer behavior and beyond. The Dryden Press, Harcourt Brace College publishers. New York.

Tolon-Kumbungu District Assembly. 2008. "Tolon-Kumbungu district profile", TKDA.

Turner, H.N (2007). Sheep production research: The development of small ruminants in the developing countries. file://c:/DocumentsandSettings/NAMA/Desktop/T.T/small ruminant 1.htm Assessed on $31^{\text {st }}$ January, 2007

Upton, M. (1985). Modules of improved production system for small ruminants. Sheep and production in humid West Africa. Proceedings of the workshop on small ruminant production system of West Africa held in Ibadan. Nigeria. January 23-26, 1984 pp 55-67.

Veterinary Services Department (VSD). (1997). National livestock Census. Livestock and information Planning Unit, Veterinary Services Department, Accra, Ghana.

Weil, P.M (1970). "The introduction of the ox plow in central Gambia." In P.F. MacLaughlin. (ed). African food production systems: Cases and theory. The John Hopkins University press. 
